\title{
Development and application of an economic ranking index for perennial ryegrass cultivars
}

\author{
M. McEvoy, ${ }^{1}$ M. O’Donovan, and L. Shalloo \\ Animal \& Grassland Research and Innovation Centre, Teagasc, Moorepark, Fermoy, Co. Cork, Ireland
}

\begin{abstract}
Economic values in euros $(€)$ were calculated for traits of economic importance in Irish grass-based systems. The economically important traits selected were spring, midseason, and autumn grass dry matter (DM) yield $(€ / \mathrm{kg}$ of DM per ha), grass quality ( $€$ per unit DM digestibility), first- and second-cut silage DM yield $(€ / \mathrm{kg}$ per ha), and sward persistency $(€ / \%$ change in persistency per ha per yr). The economic value for each trait was calculated by changing the trait of interest while keeping all other traits constant, using the Moorepark Dairy Systems Model. Herd parameters (including cow numbers and calving pattern), milk production, energy demand, supplementary feeds, and land area were readjusted to calculate the economic value for the trait of interest. The base scenario assumed fixed cow numbers with 40 ha of land available, with full costs included. The results for the base scenario show the economic values were: $€ 0.15 / \mathrm{kg}$ of $\mathrm{DM}$ spring yield, $€ 0.03 / \mathrm{kg}$ of midseason yield, $€ 0.10 / \mathrm{kg}$ of DM autumn yield, the quality value was $€ 0.001, € 0.008, € 0.010$, €0.009, $€ 0.008$, and $€ 0.006$ per unit change in DM digestibility $/ \mathrm{kg}$ of DM yield for the months of April, May, June, July, August, and September, respectively; $€ 0.036 / \mathrm{kg}$ of DM first-cut silage; €0.024/kg of DM second-cut silage; and $-€ 4.961$ per $1 \%$ decrease in persistency/ha per yr. Sensitivity of the economic values to changes in milk price and scenario were tested. The economic values were applied to experimental production data collected over $3 \mathrm{yr}$ for 20 perennial ryegrass cultivars to establish the total economic merit for each cultivar and then to rank each cultivar based on its economic performance. Rank correlations between the base and alternative scenarios ranged from 0.90 to unity. This indicates that the economic values are reliable regardless of system, intensity, or price. The total merit index will identify the cultivars that can make the greatest economic contribution to a grass-based production system.
\end{abstract}

Received April 7, 2010.

Accepted November 18, 2010.

${ }^{1}$ Corresponding author: mary.mcevoy@teagasc.ie
Key words: economic ranking, yield, quality, persistency

\section{INTRODUCTION}

Eighty percent of the world's bovine milk and $70 \%$ of the world's beef and veal are produced from temperate grassland cattle (Wilkins and Humphreys, 2003). Perennial ryegrass is considered one the most important forage grass species used in temperate agriculture for ruminant animal production. In Ireland, $80 \%$ of the agricultural area is devoted to pasture, hay, and grass silage (Department of Agriculture, Fisheries and Food, 2009a). Grass growth is seasonal and production is limited in the winter and early spring period, with over $95 \%$ of total grass growth occurring between the March to October period (Dillon et al., 2005). Average annual grass DM production ranges from $11 \mathrm{t}$ of DM/ ha to $15 \mathrm{t}$ of $\mathrm{DM} /$ ha (Brereton, 1995). Grazed grass is the cheapest feed available in Ireland (Finneran et al., 2010 ) with a relative cost ratio of grazed grass, grass silage, and concentrate (rolled barley) of 1:1.8:2.4. Dairy, beef, and sheep production systems generally target calving and lambing to coincide with the onset of grass growth in the spring (Dillon et al., 1995; Drennan et al., 2005; Keady et al., 2009). During the period of April to August (main grazing season), animal performance is almost entirely achieved through a grass-based diet, with excess forage harvested and conserved as silage, which provides a feed source during periods when fresh herbage availability is inadequate. Current feed budgets for dairy cows consist of $75 \%$ of grazed grass, $19 \%$ of grass silage, and $6 \%$ of concentrates (O'Donovan and Kennedy, 2007), which is similar to $61 \%$ of grazed grass, $31 \%$ of grass silage, and $8 \%$ of concentrates for calf-to-beef production systems (Drennan and McGee, 2009). Sheep production systems incorporate early or late spring lambing with sheep production being dominated by grass-based systems (Keady et al., 2009) and minimal use of supplements.

The economic merit of an individual grass cultivar across a full production year has not being quantified previously. In cattle breeding, the development of a total merit index to assist farmers in identifying the 
most profitable bulls and cows (Veerkamp et al., 2002) has been successfully adopted and accepted in many countries, including New Zealand (Breeding Worth; NZAEL, 2009), United States (AIPL, 2010), Canada (CDN, 2010), and the Republic of Ireland (Economic Breeding Index; ICBF, 2008). The development of a similar approach to rank grass cultivars would be a significant advancement in grass selection to guide grass breeders, research scientists, advisors, and farmers in identifying grass cultivars that would deliver the highest increases in profitability at the farm level. The identification and application of economic values to each trait of economic importance (DM yield, silage yield, quality, and persistency) and the presentation of grass cultivar ranking based on their total economic merit will provide the industry with information on the optimum cultivars for a system.

In developing a total merit index, it was recognized that the traits of importance were those that have the largest effect on the economic performance of a system. The key traits were determined based on those considered most important within the system following a review of several studies (Dillon et al., 1995; Drennan and McGee, 2009; Keady et al., 2009). In addition, a critical consideration in defining specific criteria for selection is the ease with which the traits can be measured (Wilkins and Humphreys, 2003). Improvement in each trait can be achieved through plant breeding. The selected traits have been identified as important by others, including breeders, research scientists, extension officers, and farmers (Casler, 2000).

The objective of this study was to develop an economic index for grass cultivar ranking, which includes all of the variables of economic importance within Irish grass-based production systems and to apply the economic values to measured cultivar performance data to determine the overall economic merit of a grass cultivar. Included as an objective was testing the relative ranking of cultivars across enterprise, production system, and price.

\section{MATERIALS AND METHODS}

\section{Moorepark Dairy Systems Model}

The Moorepark Dairy Systems Model (MDSM) is a stochastic budgetary simulation model that provides a comprehensive simulation framework integrating biological, physical, and economic processes in a model of a dairy farm (Shalloo et al., 2004). The MDSM was used to simulate herd parameters, nutritional requirements, land use, and total inputs and outputs across the calendar year. A full description of the model is reported by Shalloo et al. (2004). The major revenues in the MDSM are milk sales and livestock sales. Within the model, simulations of land area was treated as an opportunity cost, with additional land rented when required or leased out when not required for on-farm feeding of animals. Variable costs (fertilizer, concentrate, vet, medicine, artificial insemination, silage, reseeding, and contractor charges), fixed costs (car, electricity, labor, machinery operation and repair, phone, and insurance, among others), and receipts (livestock, milk, and calf) were based on current prices (Teagasc, 2008).

A spring-calving grass-based milk production system, which is similar to the production system of most Irish dairy farms (Dillon et al. 2005), was simulated using the MDSM. Cows were turned out to grass immediately postcalving. Mean calving date was February 24, with a calving interval of $365 \mathrm{~d}$ and 70,20 , and $10 \%$ of the cows calving in February, March, and April, respectively (Shalloo et al., 2004). To achieve this, breeding started on a fixed calendar date in late April, with every cow detected in estrous served using AI. Regardless of the number of days since calving, the breeding season was confined to a 13-wk period (Shalloo et al., 2004).

The base scenario assumed in this study had 40 ha of land with 84 cows. Cow numbers were fixed to isolate the herbage effects from the animal effects in the model. In the base scenario, total annual DM production was assumed to be $13 \mathrm{t}$ of $\mathrm{DM} /$ ha, based on measurements at Moorepark (1982 to 2001; Shalloo et al., 2004). The system optimizes the use of grazed grass as a proportion of the total diet of the lactating dairy cow, allowing high cow performance, while minimizing the cost of milk production. The net energy system described by Jarrige (1989) was used to determine the energy requirements of the system. Monthly forage fill values (FV) and feed units for lactation (UFL) values within the model were calculated using average monthly values calculated from the chemical composition of 98 swards sampled from the Moorepark Research Farm between 2001 and 2008 (B. O'Neill, Teagasc, Moorepark, Fermoy, Co. Cork, Ireland, personal communication). The FV and UFL values were used to calculate the energy supplied by the diet. Dry matter intake was calculated based on the FV of the sward, the intake capacity (IC), and the energy requirements of the animal (maintenance, milk production, and pregnancy). The proportions of feed offered (grass, grass silage, and concentrate) were adjusted to meet the $\mathrm{NE}_{\mathrm{L}}$ requirements, maintenance, and BW change (Shalloo et al., 2004), while optimizing the proportion of grazed grass in the diet (Dillon et al., 1995). The grass proportion in the diet increased as grass supply in the system increased. The average annual milk production per cow was $6,238 \mathrm{~kg}$, with 37.0 $\mathrm{g}$ of fat $/ \mathrm{kg}, 33.4 \mathrm{~g}$ of protein $/ \mathrm{kg}$, and $46.6 \mathrm{~g}$ of lactose/ $\mathrm{kg}$. The lactation curves within the MDSM for milk 
Table 1. Default parameter values in the Moorepark Dairy Systems Model

\begin{tabular}{lc}
\hline Variable & $\begin{array}{c}\text { Default } \\
\text { value }\end{array}$ \\
\hline Farm size $($ ha) & 40 \\
Gross milk price $(€ / \mathrm{L})$ & 0.27 \\
Fat price $(€ / \mathrm{kg})$ & 3.13 \\
Protein price $(€ / \mathrm{kg})$ & 6.27 \\
Price ratio of protein:fat & $2: 1$ \\
Opportunity cost of land $(€ / \mathrm{ha})$ & 297 \\
Concentrate costs $(€ / \mathrm{t})$ & 220 \\
Fertilizer costs $(€ / \mathrm{t})$ & \\
Calcium ammonium nitrate & 280 \\
Urea & 360 \\
N:P:K fertilizer $(0: 7: 30)$ & 340 \\
First-cut grass silage, including & 284 \\
contractor charges $(€ /$ ha) & \\
Second-cut grass silage, including & 235 \\
contractor charges $(€ /$ ha) & \\
Reseeding costs $(€ /$ ha) & 496 \\
\hline
\end{tabular}

yield and milk composition were based on national milk supply profiles calculated using the standard lactation curve method (Olori and Galesloot, 1999).

The area required for silage within the model was calculated based on the requirement of the herd for silage and the yield per hectare for the 2 silage harvests. This resulted in $37 \%$ of the farm closed for first-cut silage and $25 \%$ closed for second-cut silage. The total yield for both first and second cut was calculated on the assumption that $80 \%$ of the DM harvested was used. The utilizable silage yield per hectare was $4,435 \mathrm{~kg}$ (first cut) and $3,558 \mathrm{~kg}$ of DM/ha (second cut).

\section{Assumptions}

The key assumptions used in the MDSM are shown in Table 1. The base gross milk price received was $27 \mathrm{c} / \mathrm{L}$ (Binfield et al., 2008). The ratio of fat-to-protein price was $1: 2$ with a fat price of $3.42 € / \mathrm{kg}$ and a protein price of $6.84 € / \mathrm{kg}$. An opportunity cost of $€ 297 /$ ha was placed on all land in the system.

\section{Scenario Analysis}

Sensitivity analysis was used to determine the effect of a change in the production system efficiencies and price on the economic value of each trait compared with that of the base value. Several scenarios $(\mathbf{S})$ were evaluated, which deviated from the base scenario:

1) fixed cow numbers, with land area fluctuating (S1),

2) fixed land area (40 ha), with cow numbers fluctuating (S2), and

3) variations in total DM yield per hectare (S3)
a) $15 \mathrm{t}$ of $\mathrm{DM} / \mathrm{ha}$
b) $11 \mathrm{t}$ of $\mathrm{DM} / \mathrm{ha}$.

All scenarios were tested with 3 different milk prices $(22 \mathrm{c} / \mathrm{L}, 27 \mathrm{c} / \mathrm{L}$, and $30 \mathrm{c} / \mathrm{L})$.

\section{Trait Definition and Methodology to Calculate Economic Values}

The traits of importance for grass-based systems were identified as 1) DM yield (in spring, midseason, and autumn), 2) quality, 3) silage DM yield (of first and second cut), and 4) sward persistency.

Economic values were derived by simulating a physical change for each trait of interest independently. The difference between the net margin per hectare before (default) and after the change was simulated, and was divided by the change in the trait of interest to calculate the economic value for a unit change in that trait. Thus, the economic value of a trait can be described as follows:

$$
\text { Economic value }=\frac{\Delta \text { net margin per hectare }}{\Delta \text { in trait of interest }} .
$$

Spring. The economic value for an increase in spring DM yield is calculated based on the assumption that each additional $1 \mathrm{~kg}$ of DM of grass grown during the spring period will be grazed by an animal. The additional $1 \mathrm{~kg}$ of grass will displace grass silage and concentrate on an equal energy basis. Thus,

$$
\begin{aligned}
& \text { Euro per 1-kg increase in spring DM yield } \\
& =\frac{\Delta \text { net margin per hectare }}{\Delta \text { grass intake per hectare }} \times \text { utilization. }
\end{aligned}
$$

Midseason. Midseason DM yield is calculated on the assumption that each additional $1 \mathrm{~kg}$ of DM grass produced across the main grazing season will allow an increase in the carrying capacity of the farm, thereby allowing a higher stocking rate to be maintained in the same area. Therefore,

$$
\begin{aligned}
& \text { Euro per 1-kg increase in midseason DM yield } \\
& =\frac{\Delta \text { net margin per hectare }}{\Delta \text { grass grown per hectare }} \times \text { utilization. }
\end{aligned}
$$

Autumn. The economic value for an increase in autumn DM yield is calculated based on the assumption that each additional $1 \mathrm{~kg}$ of grass grown during the autumn period will be grazed by an animal. The additional $1 \mathrm{~kg}$ of grass will displace grass silage and concentrate on equal energy basis. Thus, 
Euro per 1-kg increase in autumn DM yield $=\frac{\Delta \text { net margin per hectare }}{\Delta \text { grass intake per hectare }} \times$ utilization .

The economic values for the spring, midseason, and autumn DM yields were calculated assuming a grass utilization of $90 \%, 85 \%$, and $80 \%$, respectively (O'Donovan and Kennedy, 2007).

Quality. The voluntary DMI (VDMI) of forages for lactating dairy cows is transformed into $\mathrm{FV}$ and expressed as fill units (FU) for lactating dairy cows (LFU; Jarrige, 1989). If the forage is fed ad libitum as the sole feed, the VDMI of the forage is obtained by dividing the feed IC of the animal by the FV expressed in the same FU of the forage (Jarrige, 1989). A negative relationship exists between VDMI and LFU. The IC of a lactating dairy cow is calculated as

$$
I C=\left\{\begin{array}{l}
13.9+[0.015(B W-600)]+\left(0.15 \times M Y_{P o t}\right) \\
+[1.5 \times(3-B C S)]
\end{array}\right\} \times I L \times I P \times I M,
$$

where $M Y_{P o t}=$ potential milk yield; $I L=$ indices of lactation $=a+(1-a) \times\left(1-e^{-0.16 \times \text { week of lactation }}\right)$, where $a=0.6$ for primiparous and 0.7 for multiparous cows, $e$ $=$ exponential, and $I L=1$ for dry cows; $I P=$ indices of pregnancy $=0.8+0.2 \times\left(1-e^{-0.25 \times(40-\text { wk of pregnancy })}\right)$; and $I M=$ indices of maturity $=-0.1+1.1 \times(1-$

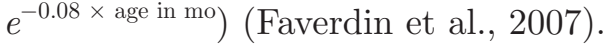

High FV indicate forages with lower rates of digestibility. In order to calculate the economic value of a unit change in DM digestibility (DMD), it is necessary to determine the effect a reduction in sward quality will have on animal intake and milk yield. In the model, the quantity of feed offered was adjusted to meet the net energy requirement of the system when forage quality changed. If the LFU of a sward was less than the calculated IC of the dairy cow, then quality affected energy intake and the resulting economic value was based on the feed requirement change. If the LFU of the sward was greater than the calculated intake requirement, then the energy intake requirement could not be satisfied and the performance of the animal was decreased, thereby resulting in a negative effect on production. For each month of April to September (inclusive), the economic effect of a $1 \%$ change in sward DMD on DMI, corrected for LFU, was calculated as follows:

Euro per unit increase in DMD value

$$
=\frac{(\Delta \text { net margin per hectare } \times \text { utilization })}{\% \text { unit } \Delta \text { DMD }} \text {. }
$$

First-Cut Silage. The value of an increase in DM yield above the base DM yield for first-cut silage was calculated based on

$$
\begin{aligned}
& \text { Euro per 1-kg increase in first-cut silage yield } \\
& =\frac{\Delta \text { net margin per hectare }}{\Delta \text { first-cut silage yield per hectare }} \times \text { utilization. }
\end{aligned}
$$

Second-Cut Silage. The value of an increase in DM yield above the base DM yield for second-cut silage was calculated based on

Euro per kg increase second-cut silage yield

$$
=\frac{\Delta \text { net margin per hectare }}{\Delta \text { second-cut silage yield per hectare }} \times \text { utilization. }
$$

Dry matter losses from mowing, wilting, and harvesting of approximately $3 \%$ have been reported (Forristal et al., 1995; Rotz, 1995), with $17 \%$ of losses occurring during the ensiling and feeding processes (P. O'Kiely, Teagasc, Grange, Co. Meath, Ireland, 2008, personal communication). Thus, total losses of harvestable DM are $20 \%$ and, hence, a utilization rate of 0.80 was assumed in the calculation of the economic values for both first- and second-cut silage DM yields.

Persistency. The economic value for persistency was derived by assuming a $10-y r$ period as the standard sward longevity based on current recommendations. The economic value for persistency was calculated based on a $1 \%$ change in the lifetime of the sward relative to the base scenario set at $10 \mathrm{yr}$ and was calculated as follows:

$$
\begin{aligned}
& \text { Euro per } \% \text { change in persistency per hectare } \\
& =\frac{\Delta \text { net margin per hectare }}{\% \text { change in persistency relative to a } 10 \text {-yr base }} .
\end{aligned}
$$

\section{Cultivar Ranking}

The model parameters were investigated through the application of the economic values to production data of 20 perennial ryegrass cultivars sown at Moorepark Dairy Research Centre, on a free-draining, acid brown earth soil with a sandy loam texture. The experimental design was a randomized complete block with 120 plots $(1.5 \times 5 \mathrm{~m})$ and a $20 \times 2$ factorial arrangement of treatments. Two management systems were applied. Management 1 represented a typical grazing rotation system used at the farm level (simulated grazing) and management 2 represented a 2 -cut silage system. Plots 
were replicated 3 times within each management. All plots were harvested to $4 \mathrm{~cm}$ in November 2006. Dry matter yield was determined over 3 yr (2007 to 2009 inclusive) and sward quality was measured over $2 \mathrm{yr}$ (2007 and 2008). Plots were harvested with an Etesia mechanical mower (Etesia UK Ltd., Warwick, UK) to a height of $4 \mathrm{~cm}$ and $\mathrm{N}$ fertilizer, in the form of calcium ammonia nitrate, was applied within $3 \mathrm{~d}$ of defoliation.

The simulated grazing management incorporated 10 defoliations annually; the first annual cut was taken on March 23, with cuts 2 to 6 taken at intervals of $3 \mathrm{wk}$ and cuts 7, 8, 9, and 10 taken at intervals of 4 to $5 \mathrm{wk}$, with the final cut taken in the first week of November. Nitrogen was applied at the rate of $365 \mathrm{~kg}$ of $\mathrm{N} /$ ha with approximately $50 \mathrm{~kg}$ of $\mathrm{N} / \mathrm{ha}$ applied $4 \mathrm{wk}$ before the first cut and thereafter, $35 \mathrm{~kg}$ of $\mathrm{N} /$ ha was applied after all cuts except the final cut, annually. The 2-cut silage management system was designed to mimic a mixed grazing and conservation system. It incorporated a harvest in early April, followed by 2 silage harvests at regrowth intervals of $7 \mathrm{wk}$ (cut 2; first-cut silage) and 6 wk (cut 3; second-cut silage), followed by 3 backend simulated grazing harvests, taken at regrowth intervals of 4,5 , and 5 wk, for cuts 4,5 , and 6 , respectively. In total, 6 defoliations were taken from mid-March to mid-November. Nitrogen was applied at the rate of 350 $\mathrm{kg}$ of N/ha. Five weeks before the first cut, $40 \mathrm{~kg}$ of N/ ha was applied and 100,90,50,40, and $30 \mathrm{~kg}$ of N/ha were applied following cut 1, 2, 3, 4 and 5, respectively. No $\mathrm{N}$ fertilizer was applied after the final cut. All cuts were taken $\pm 3 \mathrm{~d}$ of targeted cutting date.

Dry matter yield was measured on each plot at every cutting date for the appropriate protocol. The full length of the plot $(5 \mathrm{~m})$ was harvested (mower width was $1.2 \mathrm{~m}$ ). All mown herbage from each plot was collected. It was weighed and subsampled $(0.1 \mathrm{~kg})$, the subsample was dried for $48 \mathrm{~h}$ at $40^{\circ} \mathrm{C}$ in a drying oven to determine the DM content. Subsequently, the dried sample was milled through a 1-mm screen. In 2007 and 2008, the DMD of each sample was estimated using near-infrared spectrometry (NIRS; FOSS 6500 NIR, Hillerød, Denmark). The reference method of Tilley and Terry (1963) was used for the DMD calibrations of the NIRS.

The production values for spring, midseason, and autumn DM yield and quality were generated from the simulated grazing management. Within this protocol, the overall grazing season was divided into spring (February 1 to April 10), midseason (April 11 to August 6 ), and autumn (August 7 onwards). Data from the first- and second-cut silage harvests in the 2-cut silage management was used to generate the first- and secondcut silage DM yields, respectively; the remainder of the data from this management was collected but not used in the analysis. Data were analyzed with repeated measures analysis using Proc Mixed in SAS (SAS Institute, 2006). All measurements were subjected to ANOVA using the following model:

$$
Y_{i j k}=\mu+Y_{i}+M_{j}+C_{k}+P_{l}+e_{i j k l}
$$

where $\mu=$ mean; $Y_{i}=$ year effect $(i=1$ to 3$) ; M_{j}=$ management effect ( $j=1$ to 2$) ; C_{k}=$ cultivar effect $(k$ $=1$ to 20$) ; P_{l}=$ plot effect $(l=1$ to 120$) ;$ and $e_{i j k l}=$ residual error term.

The total economic merit of a cultivar was calculated by applying the economic values to the biological data of each cultivar for DM yield (spring, midseason, autumn, and first- and second-cut silage). A similar calculation was used to calculate the economic merit for quality; however, an assumption was made in relation to the total monthly utilizable herbage for grazing $(1,200 \mathrm{~kg}$ of $\mathrm{DM} / \mathrm{ha})$. The calculated values for each trait are then summed to give the total economic merit of the cultivar.

Spearman rank correlations were used to determine the degree of re-ranking of cultivars when the economic values of the different scenarios were applied to their production data. The Spearman rank correlation coefficient $\left(r_{s}\right)$ was calculated using the following equation:

$$
r_{s}=1-\left(\frac{6 \sum d^{2}}{n\left(n^{2}-1\right)}\right),
$$

where $\Sigma d^{2}$ is the difference in rank change in economic performance squared and summed for all 20 cultivars, and $n$ is the number of cultivars. The $r_{s}$ returns a value between -1 and 1 , with 1 implying the exact same ranking, and 0 implying no correlation between cultivars across scenarios.

\section{RESULTS}

\section{Bio-Economic Model}

Table 2 presents the default herd parameters for a $365-d$ period (Jan to Dec), including the number of animals present, feed requirements, and land use for the base scenario. The total annual DMI (kg per cow) was $3,947,1,114$, and $366 \mathrm{~kg}$ of DM of grazed grass, grass silage, and concentrate, respectively; on a proportional basis, these correspond to $0.71,0.21$, and 0.08 of the total diet, respectively. Total milk sales were 510,776 $\mathrm{kg}$ with total fat and protein sales of 18,907 and 17,114 $\mathrm{kg}$, respectively. 
The feed budget in the model was influenced by the calving date (Table 2). Cows were turned out to grass immediately postcalving. Calving began in February with 59, 17, and 8 cows calving in February, March, and April, respectively. The corresponding proportion of grass in the feed budget of the total herd for these months was $0.2,0.5$, and 0.8 , respectively, with silage decreasing from February (0.6) to March (0.2) and being removed from the diet thereafter until November $(0.1)$.

\section{Economic Values}

Table 3 presents the key herd parameters with the effect of a change in each trait relative to the default system on feed and land requirements, milk sales, silage yields, and profit/ha. In the default scenario, the stocking rate is 1.9 cows/ha. Table 4 presents the calculated economic value for each trait.

Spring DM Yield. Simulating an increase in spring $\mathrm{DM}$ yield resulted in an additional $43 \mathrm{~kg}$ of DM/ha grass in the system (Table 3); when corrected for energy, this displaced $26 \mathrm{~kg}$ of DM silage and $24 \mathrm{~kg}$ of concentrate DM from the diet during the spring period. Total costs were decreased compared with the base scenario costs and the resultant farm profit increased by $€ 13.80 /$ ha. The economic value for an increase in spring DM yield is calculated at $€ 0.15$ per $\mathrm{kg}$ of $\mathrm{DM}$ at $90 \%$ utilization (Table 4).

Midseason DM Yield. Simulating an increase in midseason herbage production resulted in an increase of $1.3 \mathrm{t}$ of $\mathrm{DM} /$ ha of herbage grown, of which $1.1 \mathrm{t}$ of $\mathrm{DM} /$ ha is utilized. The resultant increase in farm profit was $€ 46.60 /$ ha, which corresponded to $€ 0.03$ per $\mathrm{kg}$ of $\mathrm{DM}$ at $85 \%$ utilization.

Autumn DM Yield. Simulating an increase in autumn DM yield resulted in an additional $47 \mathrm{~kg}$ of DM/ ha grass available; when corrected for energy, 27 and $23 \mathrm{~kg}$ of DM silage and concentrate, respectively, were displaced from the diet. The resultant increase in farm profit was €11.60/ha, which corresponds to €0.10 per $\mathrm{kg}$ of $\mathrm{DM}$ at $80 \%$ utilization.

Quality. Simulating a 1 unit decrease in sward DMD resulted in a negative effect on milk production in the months of May to September (inclusive). The economic value for quality expressed as $€$ per unit decrease in DMD per $1 \mathrm{~kg}$ of DM was -€0.001 for the month of April. Fill value did not affect animal intake during April; hence, no effect of grass quality on animal performance was present. During the months of May to September, the FV of the grass restricted the DMI of the animal. As a result of this restriction on intake, milk yield decreased. The resulting economic values for these months expressed as $€$ per unit decrease in
DMD per $1 \mathrm{~kg}$ of DM were as follows: $-€ 0.008$ (May), $-€ 0.010$ (June), -€0.009 (July), -€0.008 (August), and $-€ 0.006$ (September).

First-Cut Silage DM Yield. Simulating an increase in silage DM yield required less total area to be used for silage harvesting. Increased DM yield of firstcut silage resulted in an additional $445 \mathrm{~kg}$ of $\mathrm{DM} / \mathrm{ha}$ conserved. This resulted in a total of $4,880 \mathrm{~kg}$ of DM/ ha harvested as first-cut silage. The resulting total farm profit increased by €19.70/ha. The economic value for each additional $1 \mathrm{~kg}$ of DM of first-cut silage conserved was $€ 0.036$ per ha.

Second-Cut Silage DM Yield. Simulating an increase in the DM yield of the second-cut silage resulted in an increase in $356 \mathrm{~kg}$ of $\mathrm{DM} /$ ha conserved, therefore, reducing the total area required for silage by 0.8 ha compared with the base value. The resulting farm profit achieved from an increase in harvest yield of second-cut silage was $€ 10.90 /$ ha. The economic value for each additional $1 \mathrm{~kg}$ of DM of second-cut silage was $€ 0.024$ per ha.

Persistency. Simulating a $1 \%$ decrease in persistency per year will result in a decrease in net margin of $€ 4.96 /$ ha per yr. The cost of reseeding is incorporated into the calculation of the economic value at $€ 496.00 /$ ha.

\section{Scenario Analysis}

The sensitivity of the economic values to each scenario are presented in Table 5 (these values were not statistically tested). The economic values for each trait are dependant on the scenario selected as well as the relevant milk price, except for persistency, which was -€4.96/\% decrease in persistency per ha per yr, regardless of the scenario examined. As the scenario changes, the net margin per hectare is adjusted and this affects the economic value for each trait. Table 5 presents the adjusted economic values for each scenario at each milk price.

In the base scenario, at a milk price of $22 \mathrm{c} / \mathrm{L}$, the economic value, expressed as $€$ /unit change in DMD, increased slightly for the months of May to September compared with the corresponding values at a milk price of $27 \mathrm{c} / \mathrm{L}$. At a milk price of $30 \mathrm{c} / \mathrm{L}$, the economic values decreased compared with that of the base at a milk price of $27 \mathrm{c} / \mathrm{L}$ (Table 5).

In S1 (fixed cow numbers with land area fluctuating), at a milk price of $30 \mathrm{c} / \mathrm{L}$ and $27 \mathrm{c} / \mathrm{L}$, the economic value of spring and autumn DM yield decreased compared with the that of the base, whereas the economic values for midseason and silage DM yields increased (Table 5 ). The economic values of the traits at $22 \mathrm{c} / \mathrm{L}$ were similar to the base value for spring, midseason, autumn, and 
Table 2. Default herd parameters for 12 mo of a year

\begin{tabular}{|c|c|c|c|c|c|c|c|c|c|c|c|c|c|}
\hline Item & Jan & Feb & Mar & Apr & May & Jun & Jul & Aug & Sep & Oct & Nov & Dec & Total \\
\hline \multicolumn{14}{|l|}{ Animals present } \\
\hline Total cows (n) & 71 & 80 & 82 & 82 & 81 & 79 & 78 & 77 & 77 & 76 & 75 & 74 & - \\
\hline Cows milking (n) & 22 & 66 & 75 & 82 & 81 & 79 & 78 & 77 & 77 & 76 & 75 & 74 & - \\
\hline Cows dry (n) & 49 & 14 & 7 & - & - & - & - & - & - & - & - & - & - \\
\hline Cows calving (n) & - & 59 & 17 & 8 & - & - & - & - & - & - & - & - & 84 \\
\hline Replacements calving (n) & - & 12 & 3 & 2 & - & - & - & - & - & - & - & - & - \\
\hline Milk (\%) & 0.99 & 3.59 & 10.86 & 13.08 & 13.84 & 12.11 & 11.13 & 9.90 & 8.38 & 6.99 & 5.69 & 3.44 & - \\
\hline Fat concentration (\%) & 4.43 & 3.96 & 3.68 & 3.50 & 3.44 & 3.47 & 3.56 & 3.69 & 3.88 & 4.09 & 4.26 & 4.39 & - \\
\hline Protein concentration (\%) & 3.73 & 3.15 & 3.12 & 3.18 & 3.24 & 3.27 & 3.29 & 3.37 & 3.53 & 3.67 & 3.74 & 3.78 & - \\
\hline \multicolumn{14}{|l|}{ Feed requirements } \\
\hline Grass demand (kg of DM/cow per d) & 0.0 & 2.3 & 7.6 & 11.9 & 16.3 & 17.3 & 17.3 & 16.4 & 15.6 & 13.7 & 10.7 & 0.1 & - \\
\hline Silage demand (kg of DM/cow per d) & 10.9 & 7.4 & 3.6 & 0.5 & - & - & - & - & - & - & 1.4 & 13.0 & - \\
\hline $\begin{array}{l}\text { Concentrate demand } \\
(\mathrm{kg} \text { of } \mathrm{DM} / \text { cow per } \mathrm{d})\end{array}$ & 0.3 & 2.1 & 4.2 & 2.9 & 0.2 & - & - & - & - & 1.0 & 1.0 & 0.5 & - \\
\hline Total demand (kg of DM/cow per d) & 11.1 & 11.7 & 15.4 & 15.3 & 16.6 & 17.3 & 17.3 & 16.4 & 15.6 & 14.7 & 13.1 & 13.5 & - \\
\hline \multicolumn{14}{|l|}{ Proportion of different feeds in diet } \\
\hline Grazed grass & - & 0.2 & 0.5 & 0.8 & 1.0 & 1.0 & 1.0 & 1.0 & 1.0 & 0.9 & 0.8 & - & - \\
\hline Grass silage & 1.0 & 0.6 & 0.2 & - & - & - & - & - & - & - & 0.1 & 1.0 & - \\
\hline Concentrate & - & 0.2 & 0.3 & 0.2 & - & - & - & - & - & 0.1 & 0.1 & - & - \\
\hline \multicolumn{14}{|l|}{ Land use } \\
\hline Area closed for silage (ha) & - & 0.0 & 14.7 & 14.7 & 14.7 & 9.8 & 9.8 & 9.8 & 0.0 & 0.0 & 0.0 & 0.0 & - \\
\hline Area available for grazing (ha) & 40.0 & 40.0 & 25.3 & 25.3 & 25.3 & 30.2 & 30.2 & 30.2 & 40.0 & 40.0 & 40.0 & 40.0 & - \\
\hline Area cut for silage (ha) & - & - & - & - & 14.7 & - & - & 9.8 & - & - & - & - & - \\
\hline Grass growth utilized (kg of DM/ha) & - & 48.3 & 481.0 & $1,393.3$ & $1,990.3$ & $1,741.6$ & $1,876.5$ & $1,587.0$ & $1,166.3$ & 644.2 & 127.1 & 0.0 & 11,056 \\
\hline
\end{tabular}

Table 3. Key herd parameters when a unit change in trait of interest is incurred relative to the default scenario at a milk price of $27 \mathrm{c} / \mathrm{L}$

\begin{tabular}{|c|c|c|c|c|c|c|c|c|c|c|c|c|c|}
\hline \multirow[b]{2}{*}{ Herd parameter } & \multirow[b]{2}{*}{ Default } & \multicolumn{3}{|c|}{ DM yield } & \multicolumn{6}{|c|}{ Quality } & \multirow[b]{2}{*}{ Persistency } & \multicolumn{2}{|c|}{ Silage } \\
\hline & & Spring & Midseason & Autumn & Apr & May & Jun & Jul & Aug & Sept & & $\begin{array}{l}\text { First } \\
\text { cut }\end{array}$ & $\begin{array}{c}\text { Second } \\
\text { cut }\end{array}$ \\
\hline Change in trait ${ }^{1}$ & & $(+)$ & $(+)$ & $(+)$ & $(-)$ & $(-)$ & $(-)$ & $(-)$ & $(-)$ & $(-)$ & $(-)$ & $(+)$ & $(+)$ \\
\hline Herbage grown (t/ha) & 13.0 & 13.0 & 14.3 & 13.0 & 13.0 & 13.0 & 13.0 & 13.0 & 13.0 & 13.0 & 13.0 & 13.0 & 13.0 \\
\hline Herbage used (t/ha) & 11.1 & 11.1 & 12.2 & 11.1 & 11.1 & 11.1 & 11.1 & 11.1 & 11.1 & 11.1 & 11.1 & 11.1 & 11.1 \\
\hline Grass (kg of DM/cow) & 3,947 & 3,990 & 3,947 & 3,994 & 3,977 & 3,956 & 3,949 & 3,955 & 3,957 & 3,967 & 3,947 & 3,947 & 3,947 \\
\hline Silage (kg of DM/cow) & 1,114 & 1,088 & 1,114 & 1,087 & 1,114 & 1,114 & 1,114 & 1,114 & 1,114 & 1,114 & 1,114 & 1,114 & 1,114 \\
\hline Concentrate $(\mathrm{kg}$ of DM/cow) & 366 & 342 & 366 & 344 & 366 & 366 & 366 & 366 & 366 & 366 & 366 & 366 & 366 \\
\hline Farm size (ha) & 40.0 & 40.1 & 37.2 & 40.1 & 40.2 & 40.0 & 40.0 & 40.0 & 40.1 & 40.1 & 40.0 & 39.4 & 39.7 \\
\hline Area used for silage (ha) & 24.5 & 24.0 & 24.5 & 24.0 & 24.5 & 24.5 & 24.5 & 24.5 & 24.5 & 24.5 & 24.5 & 23.0 & 23.7 \\
\hline Farm stocking rate (livestock units/ha) & 2.3 & 2.3 & 2.5 & 2.3 & 2.3 & 2.3 & 2.3 & 2.3 & 2.3 & 2.3 & 2.3 & 2.4 & 2.4 \\
\hline Cows (n/ha) & 1.9 & 1.9 & 1.9 & 1.9 & 1.9 & 1.9 & 1.9 & 1.9 & 1.9 & 1.9 & 1.9 & 1.9 & 1.9 \\
\hline Milk sales (kg) & 510,776 & 510,776 & 510,776 & 510,776 & 510,776 & 504,220 & 502,492 & 503,746 & 504,522 & 506,809 & 510,776 & 510,776 & 510,776 \\
\hline Fat sales $(\mathrm{kg})$ & 18,907 & 18,907 & 18,907 & 18,907 & 18,907 & 18,682 & 18,620 & 18,657 & 18,676 & 18,753 & 18,907 & 18,907 & 18,907 \\
\hline Protein sales (kg) & 17,114 & 17,114 & 17,114 & 17,114 & 17,114 & 16,902 & 16,843 & 16,882 & 16,903 & 16,974 & 17,114 & 17,114 & 17,114 \\
\hline Silage yield first cut $(\mathrm{kg} / \mathrm{ha})$ & 4,435 & 4,435 & 4,435 & 4,435 & 4,435 & 4,435 & 4,435 & 4,435 & 4,435 & 4,435 & 4,435 & 4,880 & 4,435 \\
\hline Silage yield second cut $(\mathrm{kg} / \mathrm{ha})$ & 3,558 & 3,558 & 3,558 & 3,558 & 3,558 & 3,558 & 3,558 & 3,558 & 3,558 & 3,558 & 3,558 & 3,558 & 3,914 \\
\hline Milk returns $(€)$ & 142,847 & 142,847 & 142,847 & 142,847 & 142,847 & 141,120 & 140,641 & 140,941 & 141,090 & 141,667 & 142,847 & 142,847 & 142,847 \\
\hline Livestock sales $(€)$ & 36,978 & 36,978 & 36,978 & 36,978 & 36,978 & 36,978 & 36,978 & 36,978 & 36,978 & 36,978 & 36,978 & 36,978 & 36,978 \\
\hline Total costs $(€)$ & 152,692 & 152,136 & 150,828 & 152,226 & 152.843 & 152.729 & 152,690 & 152.719 & 152,727 & 152,778 & 152,912 & 151,902 & 152,257 \\
\hline Total profit $(€)$ & 27,134 & 27,690 & 28,998 & 27,600 & 26,982 & 25,369 & 24,929 & 25,201 & 25,342 & 25,868 & 26,914 & 27,924 & 27,569 \\
\hline Profit per hectare $(€ /$ ha $)$ & 678 & 692 & 725 & 690 & 674 & 634 & 623 & 630 & 633 & 646 & 673 & 698 & 689 \\
\hline
\end{tabular}


nomic influence of grass DM yield fluctuates across the season and is influenced by feed supply and herd demand, which agrees with Doyle and Elliott (1983). In spring and autumn, feed demand generally exceeds supply for grass-based ruminant production systems. In the main grazing season, grass supply generally exceeds herd feed demand, the extent of which is dependant on stocking rate. Each additional $1 \mathrm{~kg}$ of herbage produced in spring and autumn has a greater economic value to a grazing system than a similar increase in the midseason DM yield due to a deficit of grass in the system in the spring and autumn.

\section{Economic Traits}

The seasonal nature of ruminant production in Ireland influences the traits of importance for grass-based systems and, hence, the traits for which economic values were calculated. The key traits were determined based on those considered most valuable to the system following a review of several studies (Dillon et al., 1995; Drennan and McGee, 2009; Keady et al., 2009) and are similar to those reported by others (Casler, 2000; Wilkins and Humphreys, 2003; Department of Agriculture, Fisheries and Food, 2009b). Cultivars that provide higher DM yields in spring and autumn support the extension of the grazing season and, hence, costs of production are decreased (Moseley et al., 2001). Differences in morphological and nutritive composition between cultivars can have a significant effect on animal production performance (Vipond et al., 1997; Gowen et al., 2003; O'Donovan and Delaby, 2005). The nutritive value of perennial ryegrass varies throughout the growing season (Walsh and Birrell, 1987; Johnston, et al., 1993), as observed with the biological data of the current study. The decline in plant digestibility (May to June period) is largely associated with increases in stem content as the plant changes from vegetative to reproductive growth. Genetic improvements in DMD have resulted in measurable improvements in animal performance by increasing both diet energy content and its voluntary intake (Wilkins and Humphreys, 2003). The effect of a unit change in DMD on a monthly basis resulted in a large effect on the total merit of a cultivar. Table 7 presents the economic values applied to the production data. The range in the total value for quality is $-€ 77.33$ (cultivar 6) to $€ 71.96$ (cultivar 7). This equates to a difference of $€ 149.29 /$ ha per yr between the worst and best cultivars out of the 20 cultivars assessed on quality alone. This could have substantial effects on the overall profitability of a system. Within many cultivar evaluation trials worldwide, quality is not routinely assessed, or may only be assessed at one or 2 points across the season. This study demonstrates the need for repeated 
Table 6. Biological data of individual variety performance including the average of the 20 perennial ryegrass cultivars for yield, quality, persistency, and silage production

\begin{tabular}{|c|c|c|c|c|c|c|c|c|c|c|c|}
\hline \multirow[b]{2}{*}{ Variety } & \multicolumn{3}{|c|}{$\mathrm{DM}$ yield ( $\mathrm{kg}$ of DM/ha) } & \multicolumn{2}{|c|}{$\begin{array}{l}\text { Silage DM yield } \\
\text { (kg of DM/ha) }\end{array}$} & \multicolumn{6}{|c|}{ Quality $\mathrm{DMD}^{1}(\mathrm{~g} / \mathrm{kg})$} \\
\hline & Spring & Summer & Autumn & First cut & Second cut & April & May & June & July & August & September \\
\hline Cultivar 1 & $1,347^{\mathrm{fgh}}$ & $6,962^{\mathrm{a}}$ & $4,449^{\mathrm{a}}$ & $5,323^{\mathrm{abc}}$ & $2,960^{\text {defg }}$ & $840^{\mathrm{ab}}$ & $816^{\text {abcd }}$ & $796^{\text {abcd }}$ & 829 & $816^{\mathrm{ab}}$ & $807^{\mathrm{ab}}$ \\
\hline Cultivar 2 & $1,587^{\operatorname{defg}}$ & $6,664^{\mathrm{abc}}$ & $4,298^{\mathrm{ab}}$ & $5,349^{\mathrm{abc}}$ & $2,701^{\mathrm{fg}}$ & $833^{\mathrm{ab}}$ & $802^{\mathrm{dc}}$ & $803^{\text {abcd }}$ & 834 & $809^{\mathrm{ab}}$ & $790^{\mathrm{ab}}$ \\
\hline Cultivar 3 & $2,048^{\mathrm{ab}}$ & $6.242^{\mathrm{c}}$ & $3,948^{\mathrm{abc}}$ & $5.365^{\mathrm{abc}}$ & $3,264^{\text {abcdef }}$ & $850^{\mathrm{ab}}$ & $817^{\text {abcd }}$ & $798^{\text {abcd }}$ & 816 & $802^{\mathrm{ab}}$ & $788^{\mathrm{b}}$ \\
\hline Cultivar 6 & $1,148^{\mathrm{h}}$ & $6,178^{\mathrm{c}}$ & $3,875^{\mathrm{bc}}$ & $4,944^{\text {ac }}$ & $3,004^{\text {cdefg }}$ & $836^{\mathrm{ab}}$ & $799^{\mathrm{d}}$ & $790^{\mathrm{d}}$ & 812 & $797^{\mathrm{ab}}$ & $780^{\mathrm{b}}$ \\
\hline Cultivar 7 & $1,590^{\text {cdef }}$ & $6,396^{\mathrm{abc}}$ & $4,171^{\mathrm{abc}}$ & $5,015^{\text {ac }}$ & $3,480^{\mathrm{abcd}}$ & $857^{\mathrm{ab}}$ & $838^{\mathrm{a}}$ & $811^{\text {abcd }}$ & 834 & $828^{\mathrm{a}}$ & $818^{\mathrm{ab}}$ \\
\hline Cultivar 8 & $1,812^{\mathrm{bcd}}$ & $6,657^{\mathrm{abc}}$ & $3,895^{\mathrm{bc}}$ & $5,644^{\mathrm{ab}}$ & $3,825^{\mathrm{a}}$ & $855^{\mathrm{ab}}$ & $839^{\mathrm{a}}$ & $815^{\mathrm{ab}}$ & 821 & $825^{\mathrm{ab}}$ & $820^{\mathrm{ab}}$ \\
\hline Cultivar 9 & $1,472^{\text {defgh }}$ & $6,494^{\mathrm{abc}}$ & $4,137^{\mathrm{abc}}$ & $5,964^{\mathrm{a}}$ & $2,470^{\mathrm{g}}$ & $837^{\mathrm{ab}}$ & $805^{\text {bcd }}$ & $794^{\mathrm{bcd}}$ & 818 & $808^{\mathrm{ab}}$ & $798^{\mathrm{ab}}$ \\
\hline Cultivar 10 & $1,301^{\text {gh }}$ & $6,639^{\mathrm{abc}}$ & $4,234^{\mathrm{abc}}$ & $5,606^{\mathrm{ab}}$ & $3,240^{\text {bcdef }}$ & $832^{\mathrm{b}}$ & $806^{\mathrm{bcd}}$ & $801^{\text {abcd }}$ & 819 & $803^{\mathrm{ab}}$ & $806^{\mathrm{ab}}$ \\
\hline Cultivar 11 & $1,718^{\text {bcdef }}$ & $6,459^{\mathrm{abc}}$ & $3,853^{\mathrm{bc}}$ & $5,393^{\text {abc }}$ & $3,691^{\mathrm{ab}}$ & $861^{\mathrm{ab}}$ & $829^{\text {abcd }}$ & $808^{\text {abcd }}$ & 823 & $823^{\mathrm{ab}}$ & $809^{\mathrm{ab}}$ \\
\hline Cultivar 12 & $1.741^{\text {bcde }}$ & $6.325^{\mathrm{abc}}$ & $3.918^{\mathrm{bc}}$ & $5.626^{\mathrm{ab}}$ & $3.719^{\mathrm{ab}}$ & $860^{\mathrm{ab}}$ & $828^{\text {abcd }}$ & $817^{\mathrm{a}}$ & 827 & $813^{\text {ab }}$ & $808^{\mathrm{ab}}$ \\
\hline Cultivar 18 & $1,592^{\text {cdefg }}$ & $6,302^{\mathrm{abc}}$ & $3,825^{\mathrm{bc}}$ & $5,160^{\mathrm{abc}}$ & $3,371^{\text {abcde }}$ & $848^{\mathrm{ab}}$ & $825^{\mathrm{abcd}}$ & $806^{\text {abcd }}$ & 826 & $794^{\mathrm{b}}$ & $805^{\mathrm{ab}}$ \\
\hline Cultivar 19 & $1,300^{\mathrm{gh}}$ & $6,399^{\mathrm{abc}}$ & $4,144^{\text {abc }}$ & $5,235^{\mathrm{abc}}$ & $2,942^{\operatorname{defg}}$ & $832^{\mathrm{b}}$ & $799^{\mathrm{d}}$ & $794^{\text {bcd }}$ & $\begin{array}{l}020 \\
813\end{array}$ & $797^{\mathrm{ab}}$ & $786^{\mathrm{b}}$ \\
\hline Cultivar 20 & $1,886^{\mathrm{abc}}$ & $6,735^{\mathrm{abc}}$ & $4,183^{\mathrm{abc}}$ & $5,484^{\mathrm{abc}}$ & $3,209^{\text {bcdef }}$ & $853^{\mathrm{ab}}$ & $832^{\mathrm{abc}}$ & $802^{\text {abcd }}$ & 824 & $811^{\mathrm{ab}}$ & $786^{\mathrm{b}}$ \\
\hline SEM & 39.4 & 69.3 & 47.9 & 67.2 & 63.4 & 1.6 & 1.7 & 2.9 & 2.0 & 2.0 & 2.5 \\
\hline$P$-value & 0.001 & 0.001 & 0.001 & 0.001 & 0.001 & 0.001 & 0.001 & 0.001 & 0.01 & 0.001 & 0.01 \\
\hline
\end{tabular}

${ }^{\mathrm{a}-\mathrm{h}}$ Values in the same column not sharing a common superscript are significantly different.

${ }^{1} \mathrm{DMD}=\mathrm{DM}$ digestibility.

sampling of cultivars for quality across the months of April to September (inclusive) to accurately capture the potential of a cultivar. The development and adoption of plot harvesters equipped with NIRS, will have a major effect on the potential to achieve this. The NIRS technique provides the opportunity to estimate large numbers of samples more rapidly than do conventional laboratory analytical methods; however, its reliability

Table 7. Application of the base economic value to the biological data

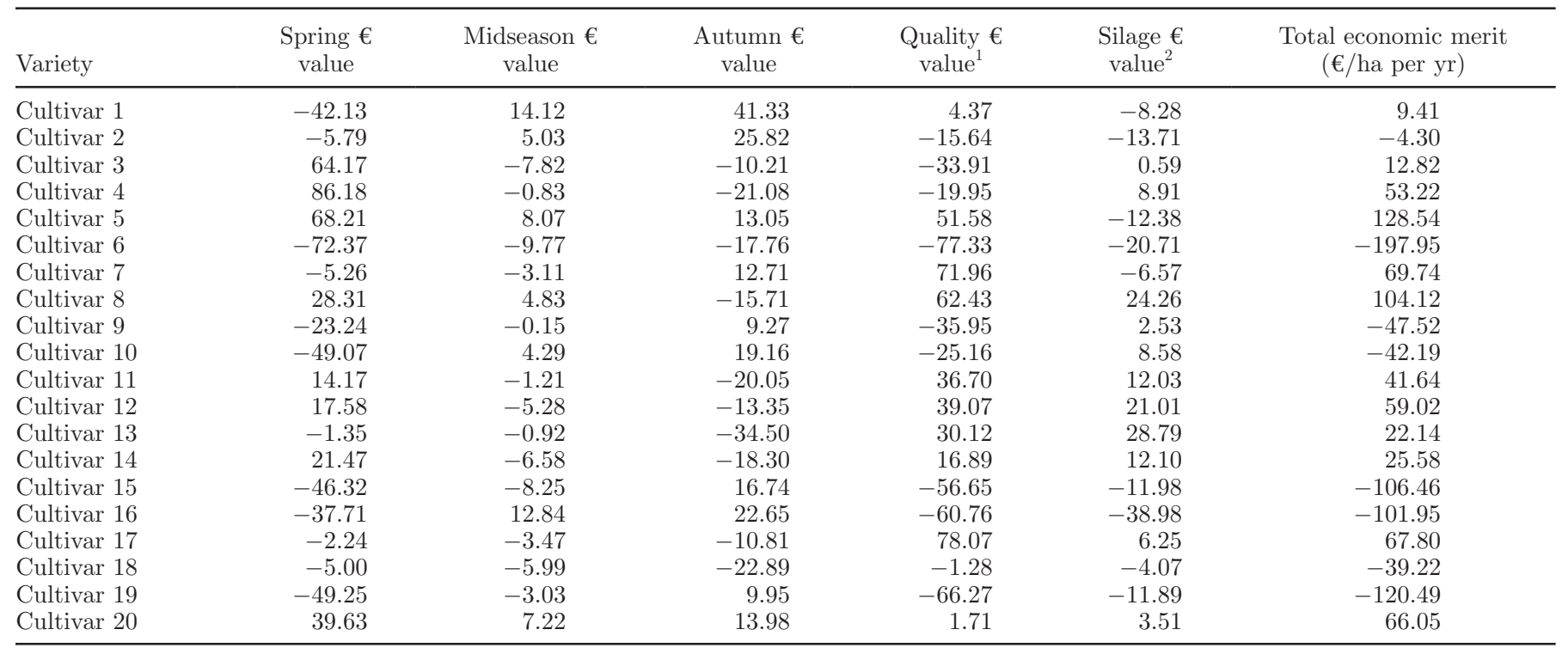

${ }^{1}$ Quality value is the sum of the quality value for the months of April to September (inclusive).

${ }^{2}$ Silage value is the sum of first- and second-cut silage values. 
is dependant on calibrations that are well distributed and represent the range of expected variation in the constituent (e.g., DMD, CP, or water-soluble carbohydrate content) of interest (Stuth et al., 2003).

High persistency is desirable, as full cultivation and reseeding of pasture is expensive (Wilkins and Humphreys, 2003). Additionally, this may have an environmental cost, as less persistent cultivars must be replaced more frequently. Ground cover score is used as a guide to the density of a sward. A low ground score indicates an open sward, which may be more susceptible to poaching, trafficability problems, or ingress by weed grass, thus, comprising the longevity of the sward. This, however, is a subjective point in-time measurement. A requirement exists to measure the lifetime performance of cultivars under animal grazing and relate this to ground score or DM yield stability. Further research in this area would be beneficial to develop a concise and rapid estimate of persistency.

\section{Overall Merit}

In animal selection, Beard (1987) reported that genetic progress could be maximized in economic terms if selection were based on the method of index selection. Such a method of selection should be directed toward a breeding objective comprising the sum of the breeding values for traits of economic importance, weighed according to their relative economic values (Beard, 1987). The total merit index for grass selection will highlight the key areas of improvement, allowing breeders to further improve grass cultivars with a strong scientific basis for the emphasis that should be placed on each trait. The higher value of an additional $1 \mathrm{~kg}$ of $\mathrm{DM}$ in the spring and autumn compared with that of the midseason period ( $€ 0.15, € 0.10$, and $€ 0.03 /$ ha per yr, respectively) will result in the breeders selecting cultivars that provide a greater proportion of their total DM yield in the spring and autumn periods. The change in economic value for DMD across the months of April to September reflects the effect of a change in UFL and $\mathrm{FV}$ on the intake potential of grass as the season advances. Through the combination of the biological and economic data, the total merit index can provide the industry with clear guidance on economically optimum cultivars.

Spearman rank correlations tested the level of reranking between cultivars across scenarios. The ranking of the cultivars within each index and subsequent comparison to the base scenario showed that cultivar rank remained relatively stable across all scenarios. Rank correlation coefficients between the base $(27 \mathrm{c} / \mathrm{L})$ and the 3 scenarios at a milk price of 22,27 , or $30 \mathrm{c} / \mathrm{L}$, ranged from 0.91 to unity (Table 8 ). This has impor-

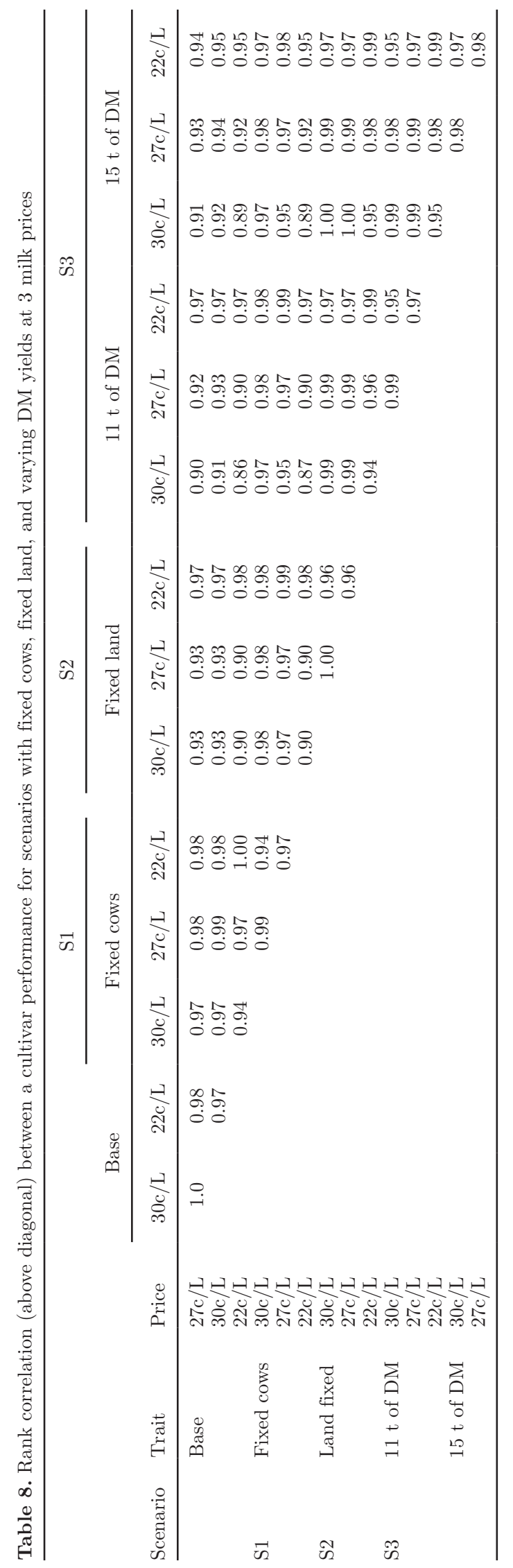

Journal of Dairy Science Vol. 94 No. 3, 2011 
tant implications for the use of a single economic index. As little or no re-ranking is occurring between indices, the developed economic values are robust. As a result, the total merit index is a reliable method to identify the cultivars that will make the greatest economic contribution to a grass-based milk production system, regardless of system, intensity, or price.

Ruminant meat systems, including beef and lamb, are highly dependant on grass-based production. A nondairy scenario was simulated to establish the overall cultivar ranking for each trait and, hence, the total merit of a cultivar. The $r_{s}$ of this scenario relative to the base scenario was high $\left(r_{s}=0.89\right)$. Within the nondairy scenario, the economic values for DM yield (spring, midseason, autumn, first- and second-cut silage) and persistency, were similar to those of the base values. It was assumed that quality had no effect on animal performance; therefore, the economic values for quality differed from the base values. In reality, this is unlikely to be the case; however, due to limited availability of data in the literature on the effect of quality on liveweight gain, the effect on performance could not be quantified. Further research needs to be conducted to investigate the effect of sward quality on animal growth and performance for beef and lamb production systems.

Gilliland and Mann (2000) and McEvoy et al., (2009) have shown that perennial ryegrass cultivars will perform differently under different management regimens. This occurs mainly due to a high degree of genetic independence between DM yield of reproductive growth (which is a major determinant of silage DM yield) and DM yield of vegetative growth (Wilkins and Humphreys, 2003). When selecting for silage yield alone, a separate index is necessary to identify the optimum cultivars in a silage-only system. The economic values calculated for a silage-only system resulted in an increase in the economic value of silage compared with the base values, but only the silage economic value will be considered when selecting cultivars for this type of system. The resulting economic value for first- and second-cut silage yield in a silage-only system were €0.099 and €0.102, respectively, per additional $1 \mathrm{~kg}$ of silage DM yield/ha.

\section{Implications}

In order to assist the farmer in optimizing production from a sward, many countries conduct independent grass cultivar evaluation trials. These trials identify cultivars that are useful, or otherwise, to conditions within that particular country (Laidlaw and Reed, 1993). Grass breeders tend to select and breed cultivars that exhibit traits that will achieve a Recommended List rating. The development of an evaluation protocol that captures the traits of interest in the economic index would allow cultivars to be ranked based on their total economic merit within the evaluation trials and, subsequently, selected based on their potential to increase the overall profitability of a grazing system.

The total merit index, in conjunction with a recommended list that captures the required traits, will present the farmer with concise economic information for cultivars that are most suitable to national conditions. Based on the individual system requirements, a farmer can then select the cultivar that will provide the greatest economic advantage to the system. In addition, the total merit index will provide breeders with information on the relative importance of one trait relative to another and, thus, allow resources to be used in the best possible manner to allow the greatest economic gains for future breeding progress.

\section{CONCLUSIONS}

The contribution of each trait to the overall economic merit of a cultivar and the resulting contribution of that cultivar to a grass-based production system can now be concisely defined. Based on the total economic merit, cultivars that provide the highest economic contribution to a system can be identified. This will enable cultivars to be ranked on their total economic merit within a grass-based production system. The total merit index will allow the advantages and shortcomings of each recommended grass cultivar to be quantified in economic terms. This will provide clear direction to grass breeders, industry stakeholders, research scientists, and farmers. Ultimately, it allows one single index to be used with confidence across grass-based systems, with changes in intensity and price.

\section{REFERENCES}

Animal Improvement Programs Laboratory (AIPL). 2010. Animal Improvement Programs Laboratory. Accessed March 19, 2010. http://aipl.arsusda.gov/Main/site_main.htm.

Beard, K. T. 1987. Efficiency of index selection for dairy cattle using economic weights for major milk constituents. Aust. J. Agric. Res. 38:273-284.

Binfield, J., T. Donnellan, K. Hanarahan, and P. Westhoff. 2008. FAPRI-Ireland Baseline 2008: Outlook for EU and Irish Agriculture. FAPRI-Ireland Partnership Teagasc, Carlow, Ireland.

Brereton, A. J. 1995. Regional and year-to-year variation in production. Pages $12-22$ in Irish Grasslands: Their Biology and Management. D. W. Jeffrey, M. B. Jones, and J. H. McAdam, ed. Royal Irish Academy, Dublin, Ireland.

Canadian Dairy Network (CDN). 2010. Canadian Dairy Network. Accessed March 19, 2010. http://www.cdn.ca/home.php.

Casler, M. D. 2000. Breeding forage crops for increased nutritional value. Adv. Agron. 71:51-107.

Department of Agriculture, Fisheries and Food. 2009a. Fact sheet on Irish agriculture-December 2009. Accessed Jan. 07, 2010. http:// www.agriculture.gov.ie/media/migration/publications/2009/ Fact\%20Sheet\%20on\%20Irish\%20Agriculture\%20Dec\%202009. doc. 
Department of Agriculture, Fisheries and Food. 2009b. Grass and Clover, Recommended List Varieties for Ireland 2009. Department of Agriculture Fisheries and Food, Maynooth, Ireland.

Dillon, P., S. Crosse, G. Stakelum, and F. Flynn. 1995. The effect of calving date and stocking rate on the performance of springcalving dairy cows. Grass Forage Sci. 50:286-299.

Dillon, P., J. R. Roche, L. Shalloo, and B. Horan. 2005. Optimising financial return from grazing in temperate pastures. Pages 131-147 in Utilisation of Grazed Grass in Temperate Animal Systems: Proceedings of a Satellite Workshop of the XXth Int. Grassl. Congr., Cork, Ireland, July 2005. J. J. Murphy, ed. Wageningen Academic Publishers, Wageningen, the Netherlands.

Doyle, C. J., and J. G. Elliott. 1983. Putting an economic value on increases in grass production. Grass Forage Sci. 38:169-177.

Drennan, M. J., A. F. Carson, and S. Crosse. 2005. Overview of animal production from pastures in Ireland. Pages 19-35 in Utilisation of Grazed Grass in Temperate Animal Systems: Proceedings of a Satellite Workshop of the XXth Int. Grassl. Congr., Cork, Ireland, July 2005. J. J. Murphy, ed. Wageningen Academic Publishers, Wageningen, the Netherlands.

Drennan, M. J., and M. McGee. 2009. Performance of spring-calving beef suckler cows and their progeny to slaughter on intensive and extensive grassland management systems. Livest. Sci. 120:1-12.

Faverdin, P., R. Delagarde, L. Delaby, and F. Meschy. 2007. Alimentation des vaches laitiers. Pages 149-180 in Alimentation des Bovins, Ovins et Caprins. QUAE Editions, INRA, Versailles, France.

Finneran, E., P. Crosson, P. O'Kiely, L. Shalloo, D. Forristal, and M. Wallace. 2010. Simulation modeling of the cost of producing and utilizing feeds for ruminants on Irish farms. J. Farm Management. 14:95-116

Forristal, P. D., P. O'Kiely, and J. J. Lenehan. 1995. Field losses with baled silage conservation systems. Pages 55-56 in Proceedings 21st Annual Research Meeting of the Irish Grassland and Animal Production Association, March 30-31, 1995, University College Dublin, Belfield, Dublin 4. Teagasc, Ireland.

Gilliland, T. J., and R. L. Mann. 2000. Effect of sward cutting management on the relative performance of perennial ryegrass varieties. J. Agric. Sci. (Camb.) 135:113-122.

Gowen, N., M. O'Donovan, I. Casey, M. Rath, L. Delaby, and G. Stakelum. 2003. The effect of grass cultivars differing in heading date and ploidy on the performance and dry matter intake of spring calving dairy cows at pasture. Anim. Res. 52:321-336.

Irish Cattle Breeders Federation (ICBF). 2008. Understanding the economic breeding index (EBI). Accessed Nov 4, 2009. http:// www.icbf.com/publications/files/Understanding_EBI_PTA_BV_ Spring_2008.pdf.

Jarrige, R. E. 1989. Ruminant Nutrition-Recommended Allowances \& Feed tables. INRA, John Libbey \& Co. Ltd., London, UK

Johnston, J. E., A. Singh, and E. A. Clark. 1993. Sward height in grazing management: Vertical profiles in sward quality. Pages 890-891 in Proceedings of XVII International Grassland Congress. Rockhampton, Australia.

Keady, T. W. J., J. P. Hanrahan, and S. Flanagan. 2009. An evaluation of two grassland-based systems of mid-season prime lamb production using prolific ewes of two genotypes. Ir. J. Agric. Food Res. 48:87-101.

Laidlaw, A. S., and K. F. M. Reed. 1993. Plant improvement: The evaluation and extension processes. Pages 385-392 in Proceedings of XVII International Grassland Congress. Rockhampton, Australia.

McEvoy, M., M. O'Donovan, and L. Shalloo. 2009. Evaluating the economic performance of grass varieties. Pages 79-85 in Proceedings of Teagasc National Dairy Conference-Together for Tomorrow, Mullingar and Killarney, 18 Nov.

Moseley, G., J. M. Owen, and P. K. Barriball. 2001. 'Practice into profit': The results of adopting good grassland practice on contrasting dairy farms. Pages 29-34 in The Right Mix: Blending Science and Practice in Dairying. Proceedings of the British Grassland Society Winter Meeting, Nov. 19-20, 2001. British Grassland Society, Great Malvern, Worchestershire, UK.

New Zealand Animal Evaluations Limited (NZAEL). 2009. Your index, your animal evaluation system. 2nd ed. New Zealand Animal Evaluations Limited. Accessed Feb. 15, 2010. http://www.aeu.org. nz/data/usr/Your\%20Index\%20Your\%20AE\%20System\%2Epdf.

O'Donovan, M., and L. Delaby. 2005. A comparison of perennial ryegrass cultivars differing in heading date and grass ploidy with spring calving dairy cows grazed at two different stocking rates. Anim. Res. 54:337-350.

O'Donovan, M., and E. Kennedy. 2007. Using grass to reduce feed costs. Pages $63-80$ in Exploiting the Freedom to Milk, Teagasc National Dairy Conference 2007. Teagasc, Carlow, Ireland.

Olori, V. E., and P. J. B. Galesloot. 1999. Projection of partial lactation records and calculation of 305-day yields in the Republic of Ireland. Interbull Bull. 22:149-154.

Rotz, C. A. 1995. Loss models for forage harvest. Transactions of the ASABE 38:1621-1631.

SAS Institute. 2006. SAS User's Guide: Statistics. SAS Institute Inc. Cary, NC

Shalloo, L., P. Dillon, M. Rath, and M. Wallace. 2004. Description and validation of the Moorepark Dairy System Model. J. Dairy Sci. 87:1945-1959.

Shalloo, L., S. O'Donnell, and B. Horan. 2007. Profitable dairying in an increased EU milk quota scenario. Pages 20-44 in Exploiting the Freedom to Milk, Proceedings of the Teagasc National Dairy Conference 2007, Kilkenny. Teagasc, Carlow, Ireland.

Stuth, J., A. Jama, and D. Tolleson. 2003. Direct and indirect means of predicting forage quality through near infrared reflectance spectroscopy. Field Crops Res. 84:45-56.

Teagasc. 2008. Management Data for Farm Planning. Teagasc, Oak Park, Carlow, Ireland.

Tilley, J. M. A., and R. A. Terry. 1963. A two-stage technique for the in vitro digestion of forage crops. J. Br. Grassl. Soc. 18:104-111.

Veerkamp, R. F., P. Dillon, E. Kelly, A. R. Cromie, and A. F. Groen 2002. Dairy cattle breeding objectives combining yield, survival and calving interval for pasture-based systems in Ireland under different milk quota scenarios. Livest. Prod. Sci. 76:137-151.

Vipond, J. E., G. Swift, A. T. Cleland, J. Fitzsimons, and E. A. Hunter. 1997. A comparison of diploid and tetraploid perennial ryegrass and tetraploid ryegrass/white clover swards under continuous sheep stocking at controlled sward heights. 3. Sward characteristics and animal output, years 4-8. Grass Forage Sci. 52:99-109.

Walsh, G. L., and H. A. Birrell. 1987. Seasonal variations in the chemical composition and nutritive value of five pasture species in southwestern Victoria. Aust. J. Exp. Agric. 27:807-816.

Wilkins, P. W., and M. O. Humphreys. 2003. Progress in breeding perennial forage grasses for temperate agriculture. J. Agric. Sci. 140:129-150. 